SCIENCE AND INNOVATION IN THE XXI CENTURY: CRUCIAL ISSUES, DISCOVERIES AND ACHIEVEMENTS

Published: February 19, 2021 | Pages: 1-3

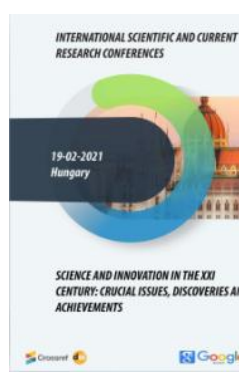

\title{
Types Of Surgical Treatment For Deviation Of The Nasal Septum
}

\author{
U.S.Khasanov \\ Department Of Otolaryngology And Stomatology Tashkent Medical Academy, Uzbekistan \\ O.R.Khayitov \\ Department Of Otolaryngology And Stomatology Tashkent Medical Academy, Uzbekistan
}

\section{J.A.Djuraev}

Department Of Otolaryngology And Stomatology Tashkent Medical Academy, Uzbekistan

\section{ABSTRACT}

Deviation of the nasal septum - natural or acquired persistent displacement of bone or cartilaginous structures, nasal septum, accompanied by impaired nasal breathing.

\section{KEYWORDS}

Deviation of nasal septum, septoplasty, nasal breathing.

\section{INTRODUCTION}

The aim of the study is to determine the indications for surgery in patients with deviation of the nasal septum, depending on local and general manifestations of deformity of the nasal septum.

\section{MATERIAL AND METHODS}

All 100 children with deviation of the nasal septum at the age from 8 to 18 years are planned to undergo examination methods, including clinical, audiological, radiological, REG research methods. The data obtained in the course of the research will be processed using Microsoft Excel 10.0 software; Statistica 10.0 using Student's t test. The control group will consist of 20 healthy individuals without pathology of the nasal cavity.

Expanded and scientifically substantiated indications for septoplasty in patients, depending on local and general manifestations of deformation of the nasal septum. For the first time, it will be proposed to take into account the state of cerebral hemodynamics and auditory function in the normal and extended frequency ranges as 
SCIENCE AND INNOVATION IN THE XXI CENTURY: CRUCIAL ISSUES, DISCOVERIES AND ACHIEVEMENTS

Published: February 19, 2021 | Pages: 1-3

additional criteria in determining the indications for septoplasty in patients.

The preserving method of surgical treatment of patients with deviation of the nasal septum in the bone region with the preservation of bone tissue in the sagittal plane with its mobilization will be improved. New methods will be developed for the treatment of patients with deformation of the nasal septum with restoration of its skeleton in the cartilaginous and bone sections, while maintaining the "growth zone".

The studies carried out will show that the presence of impaired nasal breathing caused by the deviation of the nasal septum in patients is accompanied by impaired cerebral hemodynamics and often leads to impaired auditory function.

Let us clarify the indications for septoplasty in patients, in particular, prove that additional criteria for determining indications for surgery in patients with nasal septum deviation are the results of audiometry in the conventional and extended frequency ranges and the state of cerebral hemodynamics.

\section{REFERENCES}

1. Botirov, A. J., et al. "Clinical and morphological results of xenografts to use in myringoplasty." The International Tinnitus Journal 24.1 (2020): 1-6.

2. Djuraev, Jamolbek Abdukaxorovich, et al. "Results of Allergological and Immunological Research in Patients with Polipoid Rhinosinusitis." Asian Journal of Immunology (2020): 34-40.

3. Djuraev, Jamolbek Abdukhahharovich, Ulugbek Saidakramovich Khasanov, and Ulugbek Nuridinovich Vokhidov. "The prevalence of chronic inflammatory diseases of the nose and paranasal sinuses in patients with myocarditis." European Science

Review 5-6 (2018): 147-149.

4. Normurodov, Bakhtoyor K., et al. "Prevalence and structure of purulent inflammatory diseases of the maxillofacial area." Central Asian Journal of Medicine 2020.1 (2020): 116130.

5. Jumanov, Daulet Azadbek Ugli, et al. "International Journal of Biological and Pharmaceutical Sciences Archive." International Journal of Biological and Pharmaceutical Sciences Archive 1.1 (2021): 011-015.

6. Djuraev, J. A., et al. "Results of an immunogistochemical study in patients with polipoid rhinosinusitis." European Journal of Molecular \& Clinical Medicine 7.2 (2020): 2526-2541.

7. Khasanov, U. S., and J. A. Djuraev. "Morphological characteristics of chronic polypous rhinosinusitis." cutting edge-science (2020): 30.

8. Shaumarov, A. Z., et al. "Role of Hemostatic Agents in Simultaneous Surgical Interventions in the Nasal Cavity."

9. Kurbonov, Yokubjon Khamdamovich, Shukhrat Abdujalilovich Boymuradov, and Jamolbek Abdukakharovich Djuraev. "Purulent-Necrotic Diseases Of The Face: Aspects Of Diagnostics And Treatment." The American Journal of Medical Sciences and Pharmaceutical Research 3.01 (2021): 24-30.

10. Narmurotov, Bakhtiyar Karshievich, Shukhrat Abdujalilovich Boymuradov, and Jamolbek Abdukakhkhorovich Djuraev. "Comparative Characteristics Of Rheological Properties Of Blood In Combined Face Injuries Before And After Treatment." The American Journal of Medical Sciences and Pharmaceutical Research 3.01 (2021): 67-75.

11. VOHIDOV, Ulugbek Nuridinovich, et al. "Current issues of the treatment of 
SCIENCE AND INNOVATION IN THE XXI CENTURY: CRUCIAL ISSUES, DISCOVERIES AND ACHIEVEMENTS

Published: February 19, 2021 | Pages: 1-3

chronic polypous rhinosinusitis." Journal of Biomedicine and Practice 2.5 (2020).

12. Kurbonov, Yokubjon Khamdamovich, Shukhrat Abdujalilovich Boymuradov, and Jamolbek Abdukakharovich Djuraev. "Overview Of Comprehensive Treatment of Acute PurulentInflammatory Diseases of The Face And Neck." The American Journal of Medical Sciences and Pharmaceutical Research 3.01 (2021): 15-23.

13. Nigmatov, Iftikhor Obidjonovich, et al. "Post-Traumatic Defects And Face Deformations: Features Of Diagnostics And Treatment." The American Journal of Medical Sciences and Pharmaceutical Research 3.01 (2021): 55-66.

14. Djuraev, J. A. "Improvement of comprehensive treatment vasomotor rhinitis."

15. Khasanov, U. S., U. N. Vokhidov, and J. A. Djuraev. "State of the nasal cavity in chronic inflammatory diseases of the nose and paranasal sinuses in patients with myocarditis." European science,(9 (41)).-2018 (2018).

16. Vohidov, U. N., and J. A. Djuraev. "ugli, Makhsitaliev, MI, \& Khamidjanov, s." (2020).

17. UN, Vokhidov, et al. "The local immunity in the tissues of various forms of nasal polyps." ALLERGY. Vol. 71. 111 RIVER ST, HOBOKEN 070305774, NJ USA: WILEY-BLACKWELL, 2016.

18. Vohidov, U. N. "Djuraev JA ugli, Makhsitaliev, MI, \& Khamidjanov, s. O.(2020). Current issues of the treatment of chronic polypous rhinosinusitis." Journal of Biomedicine and Practice 2.5.

19. Makhsitaliev, Mukhammadbobur, et al. "The Functional State of The Mucous Membrane of The Nasal Cavity And Paranasal Sinuses After Radical And Minimally Invasive
Surgical Interventions." The American Journal of Medical Sciences and Pharmaceutical Research 3.01 (2021): 31-40. 